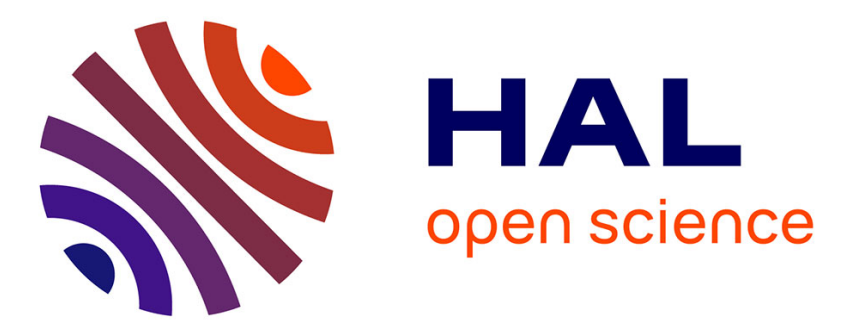

\title{
Power management based on fuzzy controller of stand-alone hybrid photovoltaic/wind system
}

Ahmed Saidi, Benachaiba Chellali, Samia Benyahia

\section{To cite this version:}

Ahmed Saidi, Benachaiba Chellali, Samia Benyahia. Power management based on fuzzy controller of stand-alone hybrid photovoltaic/wind system. International Meeting on Advanced Technologies in Energy and Electrical Engineering, Nov 2018, Fés, Morocco. hal-01941554

\author{
HAL Id: hal-01941554 \\ https://hal.science/hal-01941554
}

Submitted on 1 Dec 2018

HAL is a multi-disciplinary open access archive for the deposit and dissemination of scientific research documents, whether they are published or not. The documents may come from teaching and research institutions in France or abroad, or from public or private research centers.
L'archive ouverte pluridisciplinaire HAL, est destinée au dépôt et à la diffusion de documents scientifiques de niveau recherche, publiés ou non, émanant des établissements d'enseignement et de recherche français ou étrangers, des laboratoires publics ou privés. 
IMAT3E' 18

International Meeting on Advanced Technologies in Energy and Electrical

Engineering

\title{
I prefer: ORAL presentation
}

\section{Power management based on fuzzy controller of stand-alone hybrid photovoltaic/wind system}

\author{
${ }^{1}$ SAIDI Ahmed., ${ }^{1}$ Chellali Benachaiba., ${ }^{2}$ Benyahia Samia
}

\author{
*lead presenter \\ 1ahmedsaidi@outlook.com, Tahri Mohamed university Béchar, Algeria \\ ${ }^{2}$ Badji Mokhtar university Annaba, Algeria
}

\begin{abstract}
An off-grid energy system based on renewable photovoltaic (PV) and wind turbines (WT) generators are coupled via converters to electric and hydraulic networks. The electric network is composed of consumers and of a battery bank for electrical storage, while the hydraulic part is made of 5HP motor-pumps expected to meet the freshwater demand of a small isolated community[1], [2]. This study puts forward the prime importance of Water/Power flows management optimization. For this purpose, a Fuzzy Logic-based Energy Management Strategy (FLEMS) is proposed. Thus, both electric and hydraulic subsystems are strongly coupled in terms of energy making necessary to manage the power flows provided by renewable sources to optimize the overall system performance. In this paper, a kind of management strategies based on artificial intelligence control with the fuzzy logic controller consists of a "smart” power-sharing between the electrical and hydraulic networks with regard to the battery SOC and compared in the way they share the hybrid power sources between the storage devices and the electrical/hydraulic loads. A dynamic simulator of the hybrid energy system has been developed and tested using a MATLAB environment. Several tests are carried out using real meteorological data of the Adrar region and a practical load demand profile. The simulation results show that the "coupled strategy" clearly outperforms the classical management strategies.
\end{abstract}

\section{Simulation and results}

The simulation of the proposed hybrid Renewable sources has been accomplished using the real data of Atmospherics conditions (irradiance and wind speed) and PV-Wind power generation recorded every hour for one day the 30th July 2018 of Adrar region in Southwest Algeria. 
IMAT3E' 18

International Meeting on Advanced Technologies in Energy and Electrical

Engineering

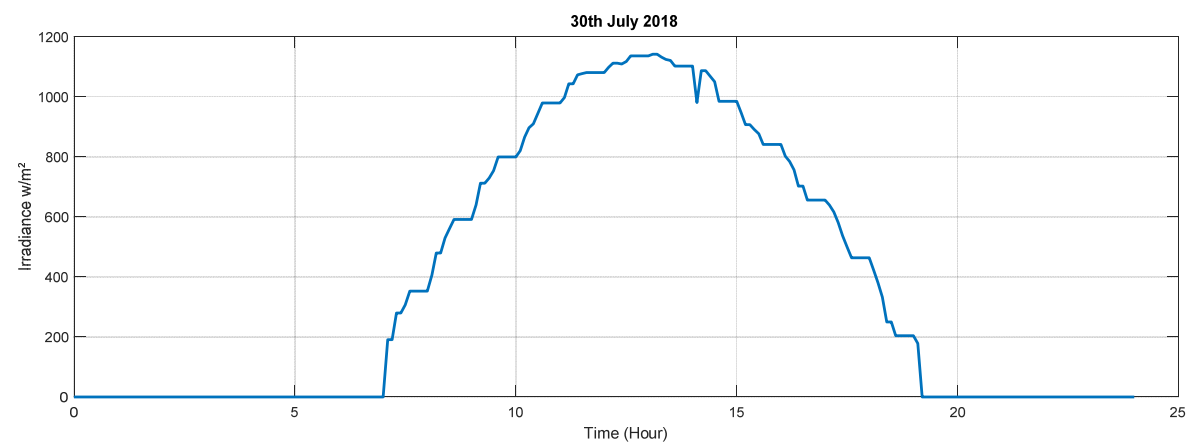

Figure 1. The irradiance of 1 day 30th July 2018.

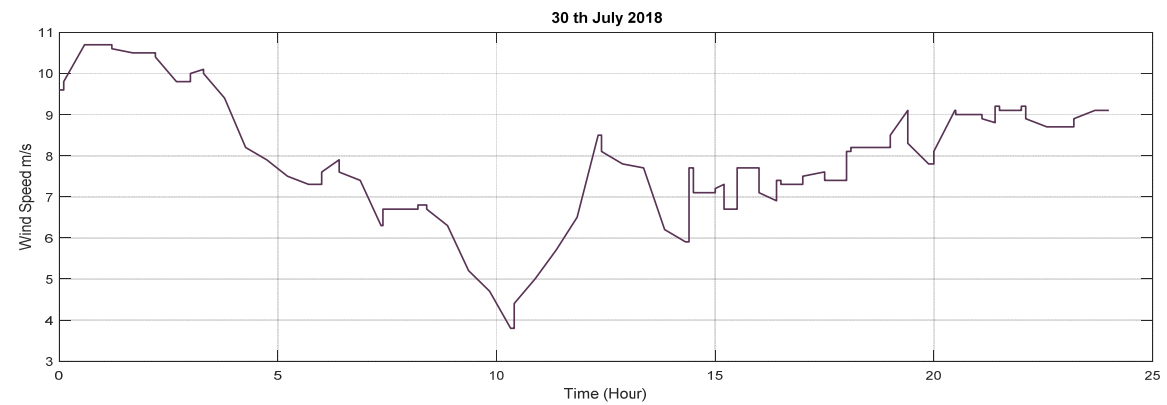

Figure 2. Wind speed of 1 day 30th July 2018.

From 00.00 AM to 05.00 AM the system is in a critical period caused by the battery discharge, in this time the wind system is incapable to satisfy the power demand, the waterpump work in a fault condition and rescued for damage.

To solve this problem, we should keep the batteries instantly charged by the time.

The PV system work 12 hours in the day, the rest hours the wind system support the load alone, the batteries bank charged in the peak when the PV and Wind systems with a maximum in the day.

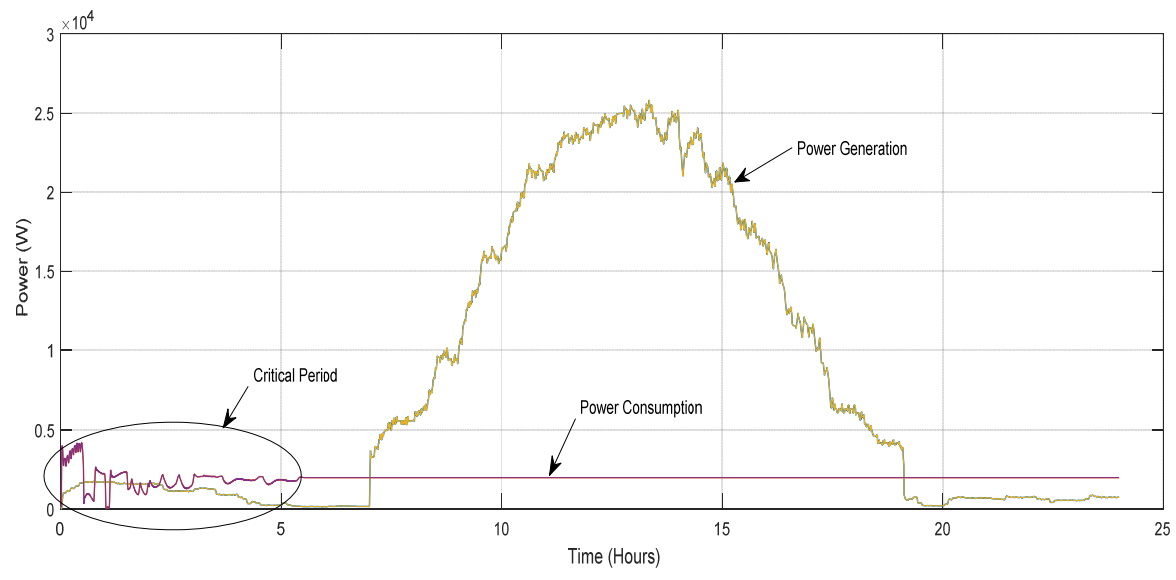

Figure 3. Wind speed of 1 day 30th July 2018. 


\section{International Meeting on Advanced Technologies in Energy and Electrical \\ Engineering}

In this paper, a specific class of standalone battery-less PV/Wind desalination system has been presented. This issue has been addressed through a specific and optimized water and power flows management strategy based on the fuzzy logic theory.

The major scientific challenge that this work contributes to rising is the development of an optimized power management system, which could work in real-time for such an autonomous system especially dedicated to remote communities[3], [4]. The sought objective through the developed this system is to produce fresh water as much as possible while taking advantage of the available electric power offered along wind speed and sun irradiation conditions. So, according to the input electric power, fuzzy rules have been used to identify the instantaneous power sharing between the two motor-pumps so that to maximize freshwater production according to the available generated power[5].

The power management system by fuzzy logic play important role in management of power generated by RES and the load presented in water-pump.

Implementing an autonomous water desalination system powered by RESs in remote areas is still being a problematic issue that needs to be carefully addressed to guarantee freshwater supply. Energy management represents the major problem of such a system and the proposed approach in this paper could be used to solve the problem in real-time, but an experimental validation needs to be carried out on the experimental test bench to confirm the simulation results and the feasibility of the proposed FLEMS.

\section{Références}

[1] A. Saidi, B. Cherif, and B. Chellali, "Fuzzy intelligent control for solar/wind hybrid renewable power system,” EEA - Electroteh. Electron. Autom., vol. 65, no. 4, 2017.

[2] F. Harrou, Y. Sun, B. Taghezouit, A. Saidi, and M. Hamlati, "Reliable fault detection and diagnosis of photovoltaic systems based on statistical monitoring approaches," Renew. Energy, 2017.

[3] S. Ahmed, C. Benoudjafer, and C. Benachaiba, "MPPT Technique for Standalone Hybrid PV-Wind Using Fuzzy Controller,” in Artificial Intelligence in Renewable Energetic Systems, 2018, pp. 185-196.

[4] F. Harrou, Y. Sun, and A. Saidi, "Model-based fault detection algorithm for photovoltaic system monitoring,” 2017 IEEE Symp. Ser. Comput. Intell. SSCI 2017 Proc., vol. 2018-Janua, pp. 0-4, 2018.

[5] A. Saidi and B. Chellali, "Simulation and control of Solar Wind hybrid renewable power system," in 2017 6th International Conference on Systems and Control, ICSC 2017, 2017. 